\title{
Positive feedback between large-scale disturbance and density-dependent grazing decreases resilience of a kelp bed ecosystem
}

\author{
John M. O'Brien ${ }^{1, *}$, Robert E. Scheibling ${ }^{1}$, Kira A. Krumhansl ${ }^{1,2}$ \\ ${ }^{1}$ Department of Biology, Dalhousie University, Halifax, Nova Scotia B3H 4J1, Canada \\ ${ }^{2}$ Present address: Hakai Institute, Simon Fraser University, Burnaby, British Columbia V5A 1S6, Canada
}

ABSTRACT: We examined how large-scale disturbances that defoliate kelp beds (outbreaks of an invasive bryozoan, hurricanes) alter local-scale grazing dynamics of an abundant herbivore, the gastropod Lacuna vincta, on the Atlantic coast of Nova Scotia, Canada. From field observations and a 5 wk kelp-thinning experiment that simulated disturbance, we found that snail density and grazing intensity on the kelp Saccharina latissima increased non-linearly with decreasing kelp biomass, as it varied within a site. Grazing intensity on S. latissima also increased non-linearly with decreasing standing kelp biomass across 5 sites spanning $40 \mathrm{~km}$ (linear distance) of coast and $2 \mathrm{yr}$, but we did not find strong support for this relationship for the kelp Laminaria digitata. Intensification of grazing augments the indirect effect of L. vincta on S. latissima (increased blade erosion and fragmentation), and drives it beyond a threshold for further losses of kelp biomass with subsequent storms. This positive feedback between large-scale disturbances and local-scale grazing could reinforce the depletion of kelp and facilitate the establishment of turf-forming algae on Nova Scotian rocky reefs. We conclude that interactions of large external perturbations with local natural perturbations must be considered to understand how drivers of ecosystem change collectively disrupt the balance of top-down and bottomup forces to cause shifts to unexpected community states.

KEY WORDS: Kelp $\cdot$ Turf-forming algae $\cdot$ Feedback · Synergy · Disturbance · Grazing · Hurricanes $\cdot$ Invasive species

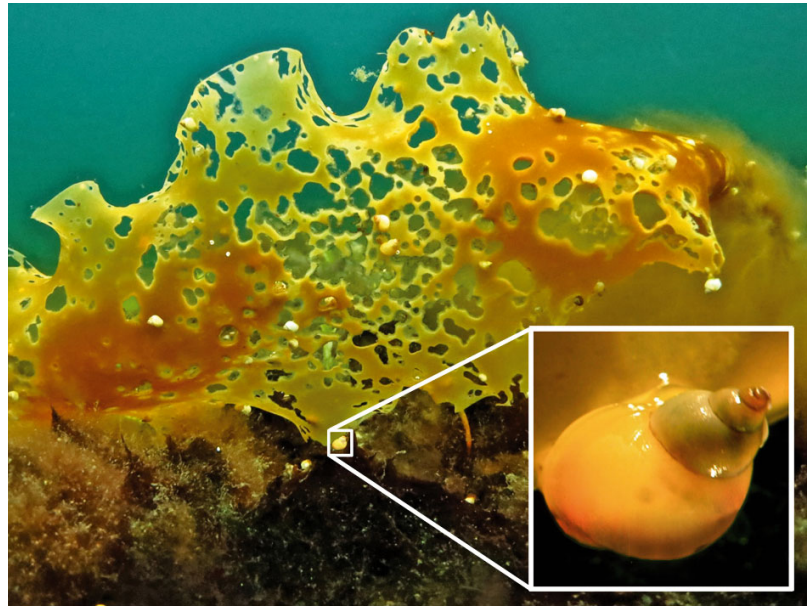

The mesogastropod Lacuna vincta aggregates on and extensively grazes a solitary kelp blade atop a thick mat of turf-forming algae.

Image: Robert Scheibling \& John O'Brien

\section{INTRODUCTION}

Large biological or physical disturbances may render populations increasingly vulnerable to further disturbances and processes that elicit, reinforce or hasten further decline (Gilpin \& Soulé 1986, Fagan \& Holmes 2006, Brook et al. 2008). Of particular concern for management and conservation is when natural disturbances and/or anthropogenic impacts interact unpredictably to produce non-additive effects (antagonism and synergism) or establish positive feedback loops (Sala et al. 2000, Burkepile \& Hay 2006, Brook et al. 2008, Crain et al. 2008, Halpern et al. 
2008). Synergies between perturbations (i.e. the total effect is greater than the sum of individual effects) are particularly common in marine systems, leading to larger or more rapid changes than anticipated (Crain et al. 2008). Consequences of such interactions include delayed population recovery (Hughes \& Connell 1999, Wernberg et al. 2010), population decline and increased extinction risk (van Katwijk et al. 1999, Brook et al. 2008), loss of biodiversity (Sala et al. 2000) and rapid changes to ecosystem structure and function (Paine et al. 1998, Hobbs et al. 2009).

Predicting and managing undesirable interactions among perturbations is complicated by the range of scales over which perturbations are compounded (global, regional, local). Impacts caused by disturbances originating at large spatial and temporal scales (e.g. climate-driven impacts) may act synergistically with the local anthropogenic stressors on which they are superimposed (e.g. nutrient loading, fishing pressure; Harley et al. 2006, Halpern et al. 2008, Wernberg et al. 2011), driving unexpected shifts to novel community states (Hobbs et al. 2009, Russell et al. 2009). An improved understanding of the mechanisms by which perturbations interact may facilitate the prediction of undesirable synergisms (Lyons et al. in press). Ecologically mediated interactions, where the effect of one perturbation on a community modifies the strength of species interactions and thus the effect of a second perturbation, may be an important interaction mechanism behind ecological regime shifts (Wernberg et al. 2010, Lyons et al. in press). The intensity of herbivory on macroalgae, for instance, may increase or decrease under future ocean warming and acidification scenarios, leaving uncertainty in the future structure of seaweed-dominated assemblages (Harley et al. 2012). How large-scale anthropogenic impacts modify local-scale perturbations intrinsic to a system, like herbivory, is therefore a critical knowledge gap. These types of interactions are arguably more difficult to mitigate through local management action compared to those involving purely anthropogenic stressors. Large disturbances that intensify grazing on competitively dominant macroalgae could facilitate competitors, leading to shifts in community structure.

Major shifts in the structure of seaweed assemblages of rocky coastlines are already underway. The replacement of productive canopy-forming macroalgae (kelps and fucoids) by turf-forming algal assemblages is increasingly reported from temperate rocky reefs globally (Eriksson et al. 2002, Worm \& Lotze 2006, Connell et al. 2008, Perkol-Finkel \& Airoldi 2010, Andersen et al. 2011, Moy \& Christie
2012). Stressors that favour the persistence of turfforming algae and inhibit the recovery of canopyforming species include eutrophication (Gorman et al. 2009), sediment loading (Airoldi 1998, Eriksson et al. 2002), fouling epiphytes (Andersen et al. 2011), ocean warming (Wernberg et al. 2010, 2012) and acidification (Russell et al. 2009, Connell \& Russell 2010), and general anthropogenic disturbance (Benedetti-Cecchi et al. 2001). These perturbations affect rocky coastlines at various spatial scales, and it is held that synergistic effects of multiple drivers can cause or exacerbate these large-scale shifts in community structure (Russell et al. 2009, Perkol-Finkel \& Airoldi 2010, Moy \& Christie 2012), although the nature of their interaction may depend on the specific identity of the drivers involved (Strain et al. 2014).

Comparable shifts in community structure have been observed along the Atlantic coast of Nova Scotia, Canada. The rocky subtidal zone, normally characterized by productive kelp beds (Saccharina latissima, Laminaria digitata), has become dominated by mixed assemblages of turf-forming algae, primarily filamentous red (Polysiphonia spp., Callithamnion spp., Antithamnion spp.) and brown (ectocarpoids) algae, that are particularly pervasive at sheltered sites from late spring to fall. This system is regularly impacted by large-scale disturbances. The encrusting bryozoan Membranipora membranacea was first reported in Nova Scotia in 1992 (Scheibling et al. 1999). Since its introduction, $M$. membranacea has become continuously distributed along the Atlantic coast of Nova Scotia (Watanabe et al. 2010). Reduced kelp tissue strength following encrustation (Krumhansl et al. 2011) results in large-scale defoliation of kelp beds in fall (Scheibling et al. 1999, Saunders \& Metaxas 2008, Scheibling \& Gagnon 2009). Defoliation of kelp along broad stretches of coast also may occur at this time owing to hurricanes tracking through the region (Filbee-Dexter \& Scheibling 2012). Understanding how these large regional impacts modify local-scale processes may offer some insight into structural shifts from kelp- to turf-dominated subtidal communities.

Reductions in kelp abundance resulting from these biological and physical disturbances could alter the grazing dynamics of the small gastropod Lacuna vincta, a numerically abundant mesograzer (1000s $\mathrm{m}^{-2}$ at seasonal peaks) that occurs on diverse algal substrates, but preferentially consumes kelp (Johnson \& Mann 1986). L. vincta is the principal grazer of kelp on the Atlantic coast of Nova Scotia when green sea urchins Stronglyocentrotus droebachiensis are rare (Johnson \& Mann 1986). This is increasingly the case due to recurrent disease-mediated mortality of 
sea urchins in shallow water (Scheibling et al. 2010, Feehan et al. 2012). Although direct consumption of kelp biomass by snails generally is small (but see Fralick et al. 1974), the indirect effects of grazing are much greater, including increased blade erosion and fragmentation caused by grazing holes and superficial excavations (Johnson \& Mann 1986, Krumhansl \& Scheibling 2011a,b, Krumhansl et al. 2011). Therefore, changes in the grazing intensity of $L$. vincta can have important implications for the persistence of kelp beds. Reductions in kelp abundance may alter grazing intensity by changing the abundance of kelp relative to snails, the rate of kelp consumption per snail (functional response) or a combination of both (total response).

In this study, we examined how large-scale disturbances (recurrent outbreaks of $M$. membranacea and hurricane damage) that reduce kelp abundance alter local-scale grazing dynamics of $L$. vincta. We measured within-site spatial variation in kelp biomass and snail density on kelp in combination with a kelp-thinning experiment to test our predictions that (1) snails will be more heavily concentrated on kelp (S. latissima, L. digitata) where it is sparse and biomass is lower, and (2) grazing intensity on S. latissima will increase with thinning of kelp. We extended our second prediction to both kelp species and a broader scale by examining standing kelp biomass and grazing damage on $S$. latissima and L. digitata at 5 sites in 2 consecutive years. We hypothesized that both spe- cies of canopy-forming kelp would be more heavily grazed at sites with lower kelp abundance.

\section{MATERIALS AND METHODS}

\section{Site descriptions}

Data for the various components of this study were collected between 2008 and 2013 from 6 sites along the Chebucto Peninsula and in St. Margarets Bay southwest of Halifax, Nova Scotia: Paddy's Head, Duncan's Cove Protected, Duncan's Cove Exposed, Splitnose Point, Cranberry Cove and The Lodge (Table 1, Fig. 1). Paddy's Head is moderately exposed with a substratum of ledges and medium to large boulders on gently-sloping bedrock. At the time of this study, kelp (predominantly Saccharina latissima) occurred in sparse and thin patches among pervasive filamentous turf-forming algae (Fig. 2A). Duncan's Cove Protected is a sheltered site supporting a dense, mixed kelp canopy of S. latissima and Laminaria digitata on small and medium-size boulders. Data from the remaining sites were collected as a part of a previous study on detrital production that included Duncan's Cove Protected (Krumhansl \& Scheibling 2011a). These sites vary in substratum type (ledges, boulders, bedrock, rocky outcrops), wave exposure (low to high) and relative abundance of kelp species (S. latissima and L. digitata; Table 1). For detailed site descriptions, see

Table 1. Location and characteristics of 6 study sites on the Chebucto Peninsula and shores of St. Margarets Bay, Nova Scotia, Canada, along with a description of the data collected from each. Types of data collected include: $B_{\mathrm{k}}$ : dry kelp biomass, $D_{\mathrm{s}}$ : density of Lacuna vincta, G: grazing intensity on kelp. The range in average kelp biomass observed at each site over the period of data collection is split by species (SL: Saccharina latissima, LD: Laminaria digitata)

\begin{tabular}{|c|c|c|c|c|c|}
\hline Site & Lat./Long. & Exposure & $\begin{array}{l}\text { Kelp biomass } \\
\left(\mathrm{g} \mathrm{m}^{-2}\right)\end{array}$ & $\begin{array}{l}\text { Data collection } \\
\text { period }\end{array}$ & Data type \\
\hline Paddy's Head (PH) & $\begin{array}{l}44^{\circ} 31.624^{\prime} \mathrm{N} \\
63^{\circ} 57.080^{\prime} \mathrm{W}\end{array}$ & Moderate, NW & $\begin{array}{l}\text { SL: } 20-75 \\
\text { LD: } 0-4\end{array}$ & 2012: Jul, Sep & $B_{\mathrm{k}}, D_{\mathrm{s}}$ \\
\hline Duncan's Cove Protected (DP) & $\begin{array}{l}44^{\circ} 29.875^{\prime} \mathrm{N} \\
63^{\circ} 31.583^{\prime} \mathrm{W}\end{array}$ & Low, E & $\begin{array}{l}\text { SL: } 350-686 \\
\text { LD: } 14-380\end{array}$ & $\begin{array}{l}\text { 2008: Sep } \\
\text { 2009: Sep } \\
\text { 2013: Jun-Jul }\end{array}$ & $\begin{array}{l}B_{\mathrm{k}}, G^{\mathrm{a}} \\
B_{\mathrm{k}}, G^{\mathrm{a}} \\
B_{\mathrm{k}}, D_{\mathrm{s}}, G\end{array}$ \\
\hline Duncan's Cove Exposed (DE) & $\begin{array}{l}44^{\circ} 29.837^{\prime} \mathrm{N} \\
63^{\circ} 31.404^{\prime} \mathrm{W}\end{array}$ & Moderate, SE & $\begin{array}{l}\text { SL: } 497-1094 \\
\text { LD: } 290-591\end{array}$ & $\begin{array}{l}\text { 2008: Sep } \\
\text { 2009: Sep }\end{array}$ & $\begin{array}{l}B_{\mathrm{k},} G^{\mathrm{a}} \\
B_{\mathrm{k},} G^{\mathrm{a}}\end{array}$ \\
\hline Splitnose Point (SP) & $\begin{array}{l}44^{\circ} 28.641^{\prime} \mathrm{N} \\
63^{\circ} 32.804^{\prime} \mathrm{W}\end{array}$ & High, SSE & $\begin{array}{l}\text { SL: } 179-245 \\
\text { LD: } 1040-1536\end{array}$ & $\begin{array}{l}\text { 2008: Sep } \\
\text { 2009: Sep }\end{array}$ & $\begin{array}{l}B_{\mathrm{k}}, G^{\mathrm{a}} \\
B_{\mathrm{k}}, G^{\mathrm{a}}\end{array}$ \\
\hline Cranberry Cove (CC) & $\begin{array}{l}44^{\circ} 30.005^{\prime} \mathrm{N} \\
63^{\circ} 55.379^{\prime} \mathrm{W}\end{array}$ & Low - Moderate, SW & $\begin{array}{l}\text { SL: } 348-382 \\
\text { LD: } 7-19\end{array}$ & $\begin{array}{l}\text { 2008: Sep } \\
\text { 2009: Sep }\end{array}$ & $\begin{array}{l}B_{\mathrm{k}}, G^{\mathrm{a}} \\
B_{\mathrm{k}}, G^{\mathrm{a}}\end{array}$ \\
\hline The Lodge (TL) & $\begin{array}{l}44^{\circ} 33.491^{\prime} \mathrm{N} \\
64^{\circ} 01.493^{\prime} \mathrm{W}\end{array}$ & Low - Moderate, NNE & $\begin{array}{l}\text { SL: } 71-317 \\
\text { LD: } 28-70\end{array}$ & $\begin{array}{l}\text { 2008: Sep } \\
\text { 2009: Sep }\end{array}$ & $\begin{array}{l}B_{\mathrm{k}}, G^{\mathrm{a}} \\
B_{\mathrm{k}}, G^{\mathrm{a}}\end{array}$ \\
\hline
\end{tabular}




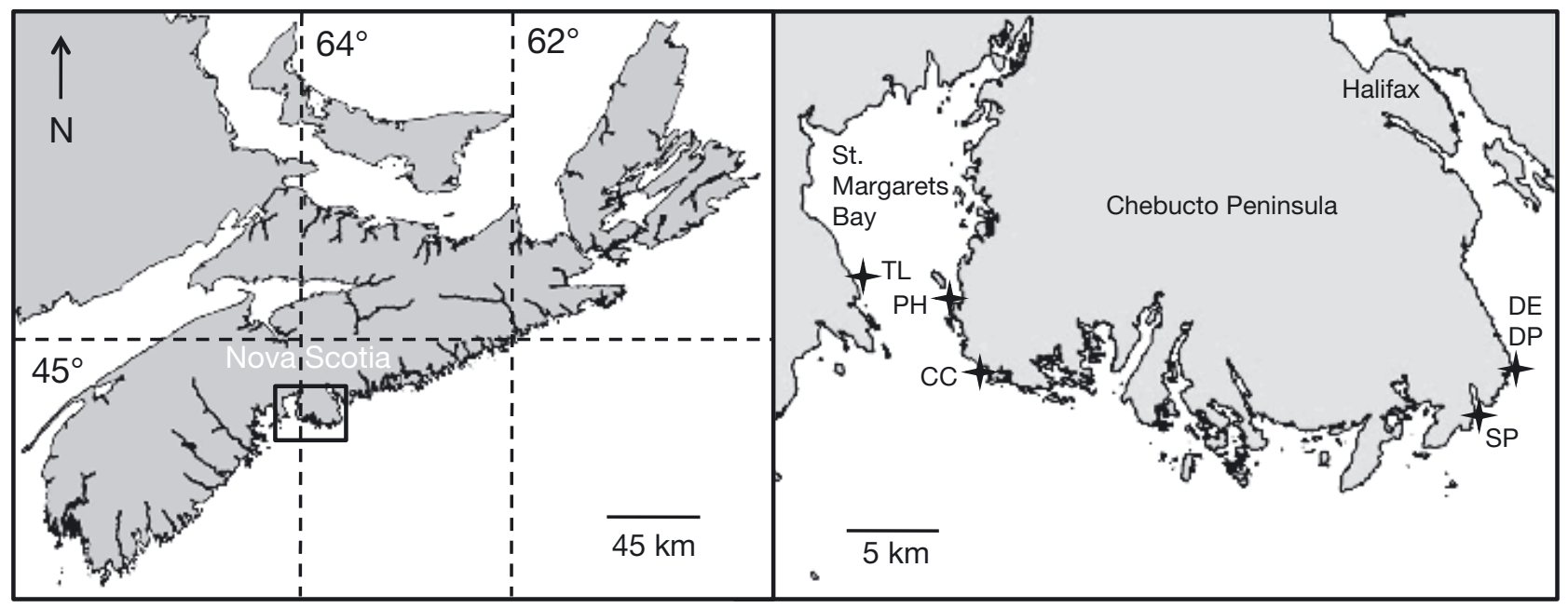

Fig. 1. Study area in the central region of the Atlantic coast of Nova Scotia, Canada, showing locations of 6 study sites along the Chebucto Peninsula and shores of St. Margarets Bay: Paddy's Head (PH); Duncan's Cove Protected (DP); Duncan's Cove Exposed (DE); Splitnose Point (SP); Cranberry Cove (CC) and The Lodge (TL)
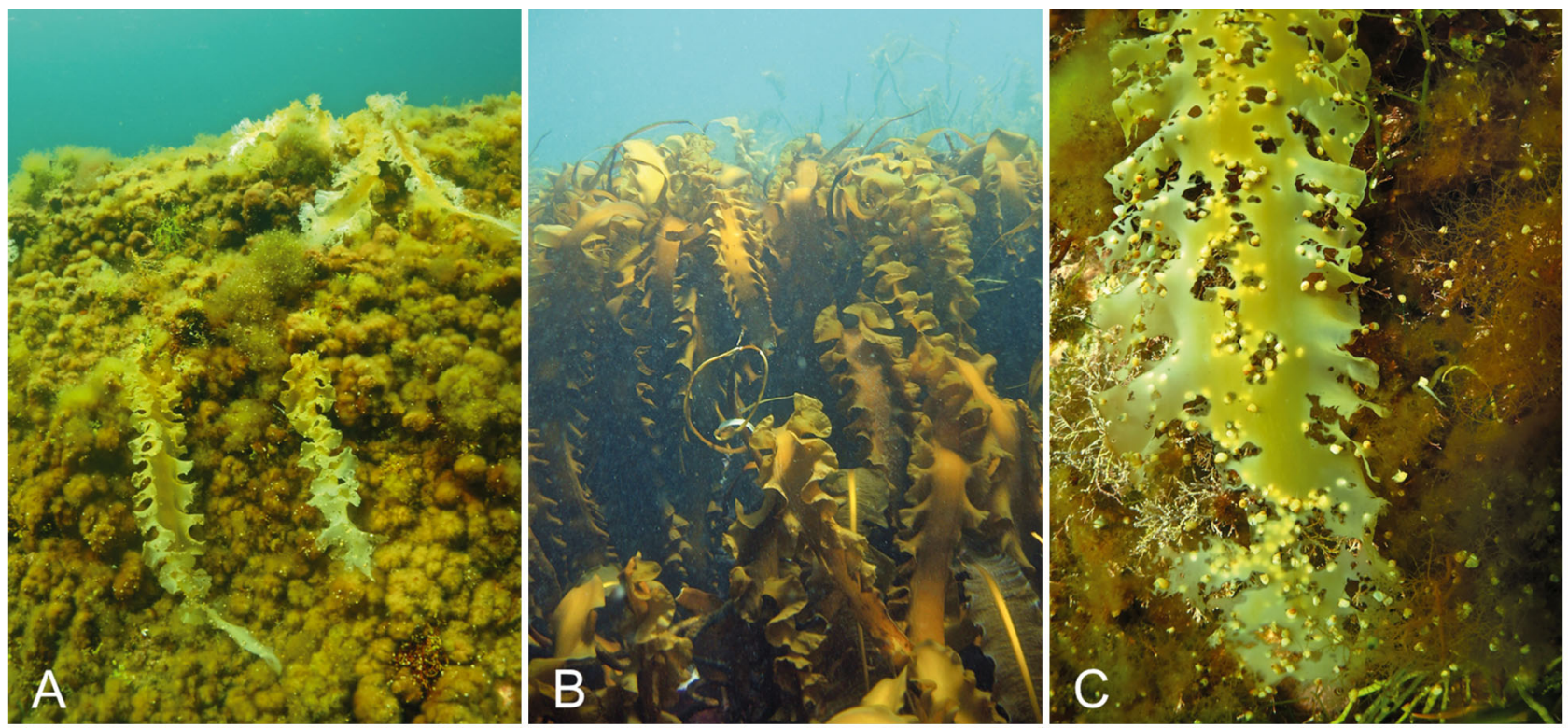

Fig. 2. (A) Sparse kelp (Saccharina latissima) amid a pervasive mat of turf-forming algae at Paddy's Head in June 2012. (B) Dense stand of kelp (S. latissima, Laminaria digitata and Alaria esculenta) at Splitnose Point in May 2007. (C) Dense aggregation of Lacuna vincta on an isolated blade of S. latissima extensively perforated by grazing at Paddy's Head in June 2012. Photographs by R. E. Scheibling

Krumhansl \& Scheibling (2011a). All collections and manipulations were made at 4 to $6 \mathrm{~m}$ depth.

\section{Grazing dynamics within sites}

To examine the potential response of Lacuna vincta to spatial variation in kelp abundance within a site (metres to 10s of metres), kelp biomass and snail density on kelp were measured using SCUBA at Paddy's
Head, once in July and once in September 2012. All macroscopic kelp (S. latissima and L. digitata) and snails on the kelp were collected in 5 to 8 haphazardly sampled $1 \mathrm{~m}^{2}$ quadrats and placed in separate fine-mesh bags. Kelp and snails were returned to the laboratory in closed bins and placed immediately in flow-through seawater holding tanks. To measure snail density on kelp (snails $\mathrm{g}^{-1} \mathrm{kelp}^{-2}$ ), all snails from each quadrat were removed from the kelp and counted. Stipes (including holdfast) and blade tissue 
of each species were weighed (0.001 g precision) separately after drying for 5 min on a paper towel. In July, tissue subsamples from the stipe and mid-blade of all measured individuals of each species were weighed as above and then oven-dried at $60^{\circ} \mathrm{C}$ for $48 \mathrm{~h}$ to calculate wet to dry weight conversions using linear regression $(S$. latissima: $\mathrm{n}=47, L$. digitata: $\mathrm{n}=7$ ). Regressions for each tissue type and species were significant at $\alpha=0.05$ with $\mathrm{R}^{2}>0.96$ (Table $\mathrm{S} 1$ in Supplement 1 at www.int-res.com/articles/suppl/ m522p001_supp.pdf) and were used to estimate the dry kelp biomass ( $g$ ) of both species combined in each quadrat.

The effect of kelp abundance on the density and grazing intensity of $L$. vincta was tested in a manipulative field experiment from 19 June to 25 July 2013 at Duncan's Cove Protected. This site was chosen for its high background density of kelp and because Membranipora membranacea is typically rare, allowing greater control over kelp abundance. SCUBA divers manipulated kelp density (and thus biomass) in experimental plots in a kelp bed to simulate the severe thinning and gap creation caused by biological and physical disturbances that dislodge and defoliate kelp (e.g. outbreaks of M. membranacea, hurricane damage). Although such disturbances can defoliate kelp across broader spatial scales (Saunders \& Metaxas 2008, Scheibling \& Gagnon 2009, Filbee-Dexter \& Scheibling 2012), the scale of our manipulations was limited by logistical constraints.

At the start of the experiment, 12 circular plots (1.2 $\mathrm{m}$ radius, $\left.\sim 4.5 \mathrm{~m}^{2}\right)$ marked with a central eyebolt and numbered tag were established along the 4 to $5 \mathrm{~m}$ depth contour. Plots were positioned to achieve $\sim 7 \mathrm{~m}$ spacing between plot centres and as much homogeneity in background kelp density as possible. Half the plots were randomly assigned to a kelpthinning treatment and the other half served as controls. In thinned plots, divers removed all macroscopic kelp at the holdfast within the plot, except for 4 individuals (S. latissima only) 50 to $70 \mathrm{~cm}$ in blade length that were marked with flagging tape. One of these individuals was located in the plot centre, and the remaining 3 were equally spaced along the perimeter of a smaller circular subplot $\left(1 \mathrm{~m}^{2}\right)$ in the centre of the larger plot (see Fig. S1 in Supplement 1). Centralizing kelp thalli in this way minimized edge effects while achieving a kelp density of $\sim 1$ thallus $\mathrm{m}^{-2}$ in the larger plot, consistent with observed kelp density for the time of year at other, low-density kelp sites (J. O'Brien unpublished data). Snails were shaken loose from removed kelp thalli and allowed to re-distribute among algal substrates. The kelp was bagged and discarded on shore. $L$. vincta is an annual species (Johnson \& Mann 1986), and it was assumed that the re-distribution of snails in thinned plots would be similar in effect to settlement of a new cohort to a kelp bed from the plankton. No kelp was removed from control plots, but 7 individuals in the same size range as thinned plots were flagged in like fashion $(1$ central thallus and 6 equally spaced thalli along the perimeter of the central subplot; Fig. S1), which permitted increased replication in anticipation of loss through dislodgement. Mean \pm SD kelp density in control plots was $21 \pm 10$ thalli $\mathrm{m}^{-2}(\mathrm{n}=6)$. Of the kelp removed from thinned plots, 5 individuals from each plot $(\mathrm{n}=30)$ were retained and transported back to the laboratory to estimate the baseline grazing intensity of $L$. vincta on S. latissima. A baseline density of snails was obtained $6 \mathrm{~d}$ later when all kelp and snails were collected from five $1 \mathrm{~m}^{2}$ quadrats in the area between plots, placed in separate fine-mesh bags and returned to the laboratory in closed bins. After $1 \mathrm{mo}$, all kelp and snails on kelp were collected from the central $1 \mathrm{~m}^{2}$ subplots and placed separately in finemesh bags to estimate final snail density in the laboratory. Collected thalli included those individuals flagged at the beginning of the experiment, which were subsequently used to estimate final grazing intensity.

Methods for measuring snail density on kelp (snails $\mathrm{g}^{-1}$ kelp $\mathrm{m}^{-2}$ ) and kelp biomass ( $\mathrm{g}$ ) at the beginning and end of the experiment were as described above. At both times, tissue subsamples of 4 to 6 individuals of each kelp species were retained from each $1 \mathrm{~m}^{2}$ quadrat or subplot for wet to dry weight conversions. All regressions were significant at $\alpha=0.05$ with $R^{2}>$ 0.85 (Table S1). To measure grazing intensity, defined as the percentage of blade area grazed by $L$. vincta, at the beginning and end of the experiment, the central part of the blade of collected individuals was separated from the convoluted margins and photographed. Before photographing, the margins were further sectioned and pressed between Plexiglas sheets. Due to their convoluted morphology, the surface area of the blade margins of $S$. latissima is much larger once sectioned. Grazing intensity was determined from photographs by outlining and measuring the blade area and total area of grazing damage on the blade using ImageJ (National Institutes of Health). L. vincta creates superficial excavations and full perforations of the blade, but only full perforations were delineated in photographs and used to estimate grazing intensity. 


\section{Grazing dynamics across sites}

To investigate how grazing intensity of L. vincta on canopy-forming kelps varies with kelp abundance at broader spatial scales (10s of $\mathrm{km})$, measurements of grazing intensity on $S$. latissima and $L$. digitata and standing kelp biomass across 5 sites from a separate study on detrital production and spanning $\sim 40 \mathrm{~km}$ (linear distance) of coast were used (Krumhansl \& Scheibling 2011a). Over this range, standing kelp biomass may differ between sites by orders of magnitude (Table 1, Fig. 2A,B). Measurements were taken at Duncan's Cove Protected, Duncan's Cove Exposed, Splitnose Point, Cranberry Cove and The Lodge in September in both 2008 and 2009 at the peak of grazing intensity (Krumhansl \& Scheibling 2011 b). Grazing damage was measured on 10 to 23 haphazardly collected thalli of each species $(>25 \mathrm{~cm}$ blade length), except for $L$. digitata at Cranberry Cove, which was not measured in either sampling period because it was rare at this site. The percent of the blade area grazed of collected thalli was measured as above, although whole thalli were photographed without sectioning the blade margins. Standing kelp biomass at the sites was estimated for each sampling period by weighing all individuals of both species in each of 8 or 9 quadrats of $0.5 \mathrm{~m}^{2}$ with a spring scale (10 g precision). Tissue subsamples (stipe and blade) of each species were taken from collected thalli during each sampling period for wet to dry weight conversions as above. All regressions were significant at $\alpha=0.05$ with $\mathrm{R}^{2}>0.8$ (Table S1). Conversions for L. digitata at Cranberry Cove were taken from literature values from a comparable site and season (Mann 1972).

\section{Statistical analysis}

Regression techniques were used to determine the effect of kelp abundance on snail density using data from collections at Paddy's Head and the field experiment at Duncan's Cove Protected. Power functions were fit to the relationships between snail density $\left(D_{\mathrm{s}}\right.$, snails $\left.\mathrm{g}^{-1} \mathrm{kelp} \mathrm{m}^{-2}\right)$ and dry kelp biomass $\left(B_{\mathrm{k}}, \mathrm{g}\right)$, in quadrats or subplots, of the form: $D_{\mathrm{s}}=\alpha\left(B_{\mathrm{k}}\right)^{\beta}$. If the number of snails on kelp in an area is constant regardless of kelp biomass (no aggregative response) or decreases more slowly than kelp biomass (type II aggregative response; see Gascoigne \& Lipcius 2004), then we expect a strong, declining power-fitting relationship between snail density on kelp and kelp biomass because biomass is essentially plotted by its inverse. Separate regressions were fit for the July and September sampling periods at Paddy's Head, and the combined data from the beginning and end of the field experiment. For comparison, a regression line also was fit to the combined Duncan's Cove Protected and Paddy's Head data (July sampling period). Regression parameters were estimated using nonlinear regression with the nls function in $\mathrm{R}$ ( $\mathrm{R}$ Core Team 2012).

To demonstrate that observed differences in snail density in the field experiment between treatments were not confounded by differences in kelp consumption by snails, the mean thallus biomass of flagged plants in thinned and control plots were compared with a 2-tailed independent-samples $t$-test. Snail density per thallus (rather than per $\mathrm{g}$ kelp) of all kelps $>30 \mathrm{~cm}$ blade length in subplots also was compared between treatments with a 2-tailed independent-samples $t$-test. For both tests, untransformed data met assumptions of normality (Shapiro-Wilk test, p > 0.05 ) and homogeneity of variances (Barlett's test, $\mathrm{p}>0.05)$

Nested ANOVA was used to test for differences in the mean grazing intensity ( $\%$ blade area grazed) between thinned and control plots at the end of the field experiment and the baseline site average at the start of the experiment, with kelp-thinning treatment as a fixed factor and plot as a random factor nested within treatment. Grazing data were $\log _{10}$-transformed to achieve normality (Shapiro-Wilk test, p > 0.05) and homogeneity of variance (Bartlett's test, p > 0.05). Where differences were detected, pairwise comparisons were made using Tukey's HSD test at a $95 \%$ family-wise confidence level.

The relationships between grazing intensity and kelp abundance for (1) S. latissima within a site (Duncan's Cove Protected in 2013) and (2) S. latissima and L. digitata across sites (5 sites in 2008/2009) represent the total response (see Murdoch \& Oaten 1975) of $L$. vincta to kelp abundance, i.e. the product of shifts in the per capita consumption rate of snails (functional response; not explored explicitly here) and the number of snails per kelp (addressed above). We applied the advice of Trexler et al. (1988) for determining the general shape of functional response curves (i.e. type I, II or III) to these total response curves, which may have analogous shapes, prior to more detailed curve-fitting (details provided in Supplement 2 at www.int-res.com/articles/suppl/ m522p001_supp.pdf). In all cases, we determined that grazing was negatively density-dependent throughout all ranges of kelp biomass (i.e. type II total response; Tables S2 \& S3 in Supplement 2). Subse- 


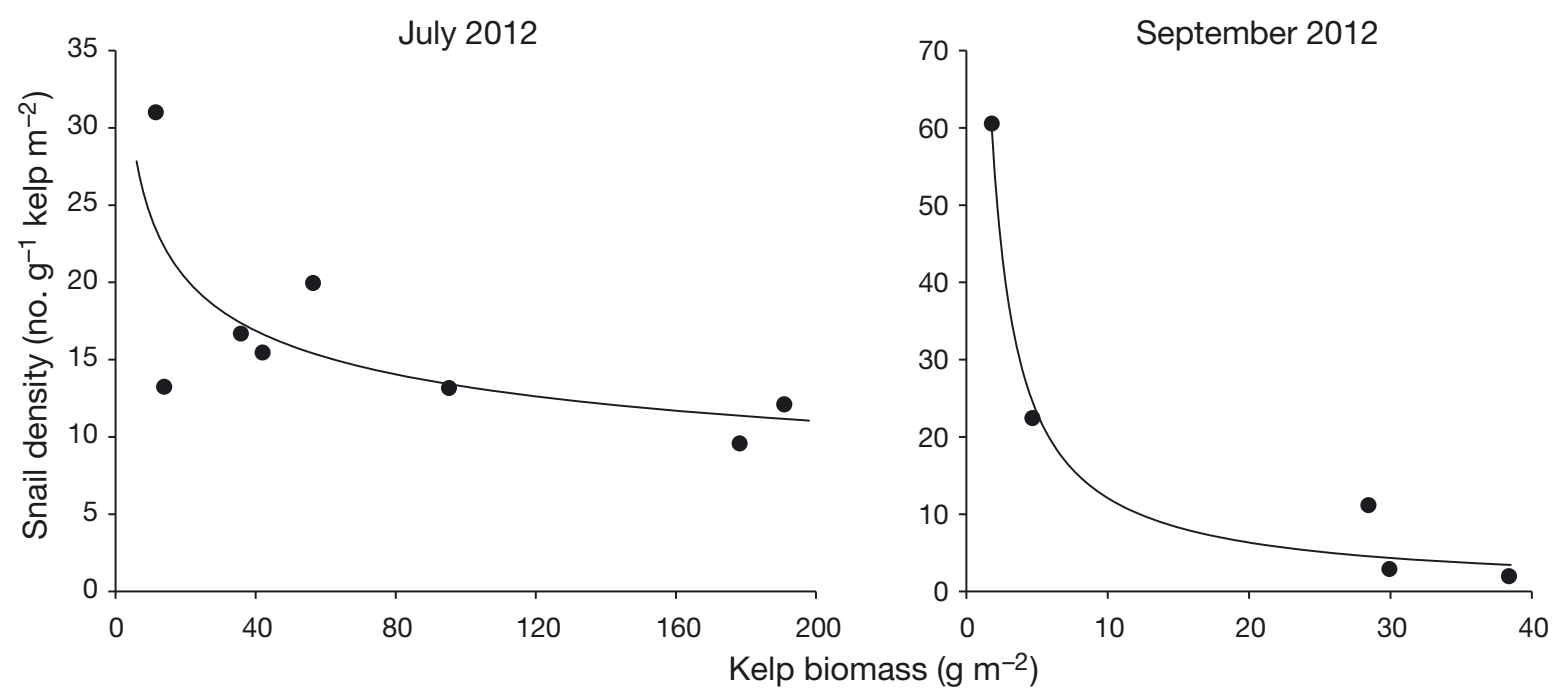

Fig. 3. Relationship between density of the gastropod Lacuna vincta on kelp (Saccharina latissima and Laminaria digitata) and kelp biomass in $1 \mathrm{~m}^{2}$ quadrats at Paddy's Head in July and September 2012 (July: $\mathrm{R}^{2}=0.469, \mathrm{p}=0.065$; September: $\mathrm{R}^{2}=0.842$, $\mathrm{p}<0.01)$. Note difference in scale on both axes for each sampling period

quently, we used power functions (as above) to model this response. Due to the error structure of these data (variance increasing with the mean), parameters were estimated by simple linear regression following a linearizing transformation of the power function: $\log Y=\log \alpha+\beta\left(\log B_{\mathrm{k}}\right)$ to meet model assumptions. Back-transformed regression lines are presented for these data. All analyses were performed using R statistical software (Version 2.15.1, R Core Team 2012).

\section{RESULTS}

\section{Grazing dynamics within sites}

The density of Lacuna vincta on kelp (Saccharina latissima and Laminaria digitata) at Paddy's Head varied with kelp abundance. In July and September 2012, snail density increased non-linearly with decreasing kelp biomass in $1 \mathrm{~m}^{2}$ quadrats (Fig. 3). A non-linear relationship was supported by a significant fit of the power function for September and a marginally non-significant fit for July (Table 2). Snail density in quadrats with the least kelp was $\sim 2$ times greater than in quadrats with the most kelp in July (13-31 vs. 10-12 snails $\mathrm{g}^{-1}$ kelp $\mathrm{m}^{-2}$ ), and an order of magnitude greater in September (61 vs. 2-3 snails $\mathrm{g}^{-1}$ kelp $\mathrm{m}^{-2}$ ). The substantial difference in September was partly owing to the lowest observed kelp biomass at this time being much lower than in July (Fig. 3).

Table 2. Coefficient estimates and standard errors of power models of the form: $Y=\alpha\left(B_{\mathrm{k}}\right)^{\beta}$, where $Y$ is snail Lacuna vincta density or grazing intensity (\% kelp blade area grazed) on Saccharina latissima or Laminaria digitata, and $B_{\mathrm{k}}$ is kelp biomass at the respective sites (see Table 1 for site abbreviations) in 2008/2009, 2012 or 2013

\begin{tabular}{|c|c|c|c|c|c|}
\hline Site and sampling period & Parameter & Estimate & $\mathrm{SE}$ & $t$ & $\mathrm{p}$ \\
\hline \multicolumn{6}{|l|}{ Snail density } \\
\hline \multirow[t]{2}{*}{ PH Jul 2012} & $\alpha$ & 44.674 & 18.584 & 2.404 & 0.053 \\
\hline & $\beta$ & -0.264 & 0.117 & -2.253 & 0.065 \\
\hline \multirow[t]{2}{*}{ PH Sep 2012} & $\alpha$ & 103.872 & 13.195 & 7.872 & $<0.01$ \\
\hline & $\beta$ & -0.934 & 0.144 & -6.466 & $<0.01$ \\
\hline \multirow[t]{2}{*}{ DP Jun-Jul 2013} & $\alpha$ & 63.211 & 15.229 & 4.151 & $<0.001$ \\
\hline & $\beta$ & -0.382 & 0.049 & -7.773 & $<0.001$ \\
\hline DP Jun-Jul 2013/PH & $\alpha$ & 57.975 & 10.486 & 5.529 & $<0.001$ \\
\hline Jul 2012 & $\beta$ & -0.353 & 0.044 & -8.015 & $<0.001$ \\
\hline \multicolumn{6}{|l|}{ Grazing intensity } \\
\hline \multicolumn{6}{|l|}{ Saccharina latissima } \\
\hline \multirow[t]{2}{*}{ DP Jul $2013^{\mathrm{a}}$} & $\log (\alpha)$ & 2.337 & 0.577 & 4.053 & $<0.01$ \\
\hline & $\beta$ & -0.270 & 0.106 & -2.538 & $<0.05$ \\
\hline $\mathrm{DP}, \mathrm{DE}, \mathrm{SP}, \mathrm{CC}, \mathrm{TL}$ & $\log (\alpha)$ & 4.067 & 1.472 & 2.763 & $<0.05$ \\
\hline Sep $2008 / 2009^{a}$ & $\beta$ & -0.785 & 0.226 & -3.473 & $<0.01$ \\
\hline \multicolumn{6}{|l|}{ Laminaria digitata } \\
\hline $\mathrm{DP}, \mathrm{DE}, \mathrm{SP}, \mathrm{CC}, \mathrm{TL}$ & $\log (\alpha)$ & 3.514 & 2.739 & 1.283 & 0.247 \\
\hline Sep $2008 / 2009^{a}$ & $\beta$ & -0.674 & 0.412 & -1.638 & 0.153 \\
\hline
\end{tabular}


The outcome of the manipulative field experiment at Duncan's Cove Protected in 2013 was consistent with observations at Paddy's Head in the previous year. Kelp biomass ranged widely in control plots at the end of the experiment (191-1070 g), and was comparable to the range observed for the site at the start in June (163-761 g; Fig. 4). Snail density varied little over this range, with little difference between control plots (mean \pm SD: $5 \pm 2$ snails ${ }^{-1} \mathrm{kelp} \mathrm{m}^{-2}$ ) and baseline values in June $\left(7 \pm 2\right.$ snails $g^{-1}$ kelp $\mathrm{m}^{-2}$ ). Kelp biomass in thinned plots was lower (39-149 g) and snail density rapidly increased to 3.5 times that observed in the highest biomass control plot (14 vs. 4 snails g ${ }^{-1}$ kelp m ${ }^{-2}$; Fig. 4). Kelp biomass and snail density in thinned plots were within the range observed at Paddy's Head (July), and the observational data closely approximate the power relationship that describes the experimental data (Table 2, Fig. 4). The mean thallus biomass of flagged individuals in control and thinned plots did not differ significantly ( $t_{39}=-1.03, \mathrm{p}=0.307$; Fig. 5). However, the number of snails per thallus was significantly higher (by 2-fold) in thinned plots $\left(t_{10}=-3.05, \mathrm{p}<\right.$ 0.05 ; Fig. 5). Therefore, it is unlikely that the observed increase in snail density (per $g$ kelp) in thinned plots is a result of confounding differences in snail consumption (and reduction of biomass) of kelp between treatments.

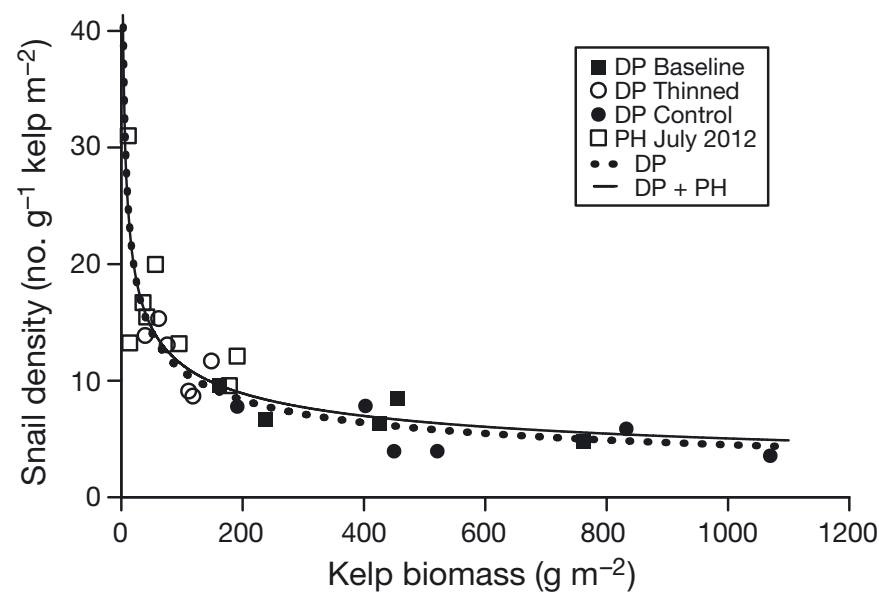

Fig. 4. Relationship between density of Lacuna vincta on kelp (Saccharina latissima and Laminaria digitata) and kelp biomass in $1 \mathrm{~m}^{2}$ quadrats and circular subplots from a manipulative field experiment at Duncan's Cove Protected (DP) in June/July 2013. Plotted points are data from quadrats at the start of the experiment (black squares), plots thinned of kelp by clearing (white circles) and control plots (black circles) at the end of the experiment. Data from Paddy's Head (PH) in July 2012 are also plotted (white squares). Separate regressions are fit to DP 2013 data only (dotted line: $\mathrm{R}^{2}=$ $0.741, \mathrm{p}<0.001$ ) and DP 2013/PH 2012 data (solid line: $\mathrm{R}^{2}=$ $0.977, \mathrm{p}<0.001)$

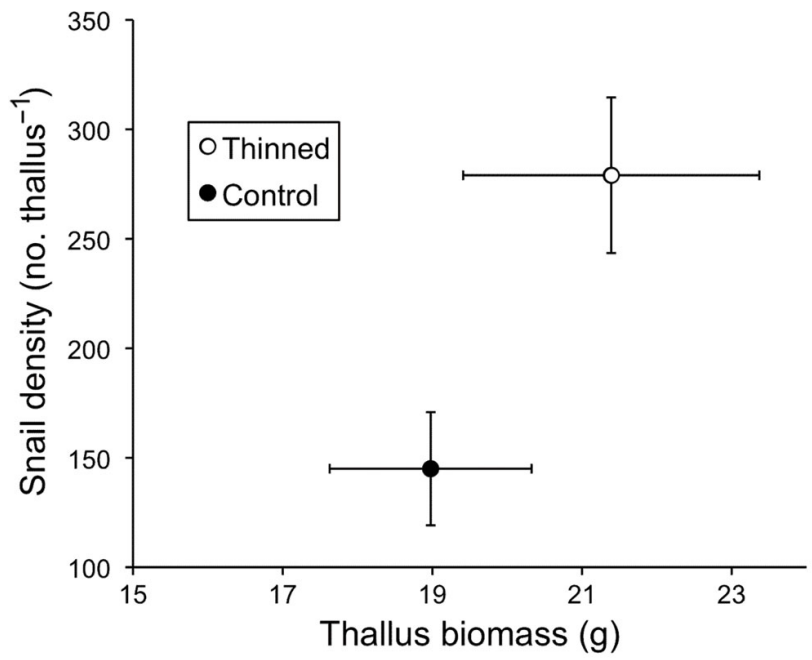

Fig. 5. Dry weight of flagged kelp thalli (Saccharina latissima) and density of Lacuna vincta (snails thallus ${ }^{-1}$ ) on kelps $>30 \mathrm{~cm}$ in blade length ( $S$. latissima and Laminaria digitata) in experimental plots thinned of kelp by clearing (white circle) and controls (black circle) at Duncan's Cove Protected in July 2013. Data are mean ( \pm SE) dry weight of kelp

(Thinned: $\mathrm{n}=17$; Control: $\mathrm{n}=24$ ) and snail density $(\mathrm{n}=6)$

Grazing intensity on $S$. latissima did not differ between control plots at the end of the field experiment (mean \pm SE: $1.9 \pm 0.04 \%$ ) and the baseline site average at the start $(1.5 \pm 0.02 \%$; Table 3, Fig. 6) However, grazing intensity in thinned plots $(3.6 \pm$ $0.07 \%$ ) was significantly higher than in control and baseline plots (Table 3, Fig. 6). There was no effect of the nested factor plot (Table 3). Grazing intensity varied with local kelp abundance similarly to snail density, although there was much more variability around this relationship (Fig. 6). Grazing intensity increased non-linearly with decreasing kelp biomass in experimental $1 \mathrm{~m}^{2}$ subplots, and the power function was a significant fit (Table 2, Fig. 6).

Table 3. Nested ANOVA comparing the mean grazing intensity ( $\%$ blade area grazed) between thinned and control experimental plots in July, and the baseline site average in June 2013 at Duncan's Cove Protected. Pairwise comparisons based on Tukey's HSD test at $95 \%$ family-wise confidence level

\begin{tabular}{|lccccc|}
\hline Source & df & MS & $F$ & p & Pairwise \\
\hline Treatment & 2 & 0.984 & 25.0 & $<0.001$ & $\begin{array}{l}\text { Baseline }= \\
\text { Control }<\end{array}$ \\
& & & & & $\begin{array}{l}\text { Thinned } \\
\text { Plot(Treatment) }\end{array}$ \\
Error & 59 & 0.062 & 1.57 & 0.111 & \\
Total & 76 & 0.039 & & & \\
\hline
\end{tabular}




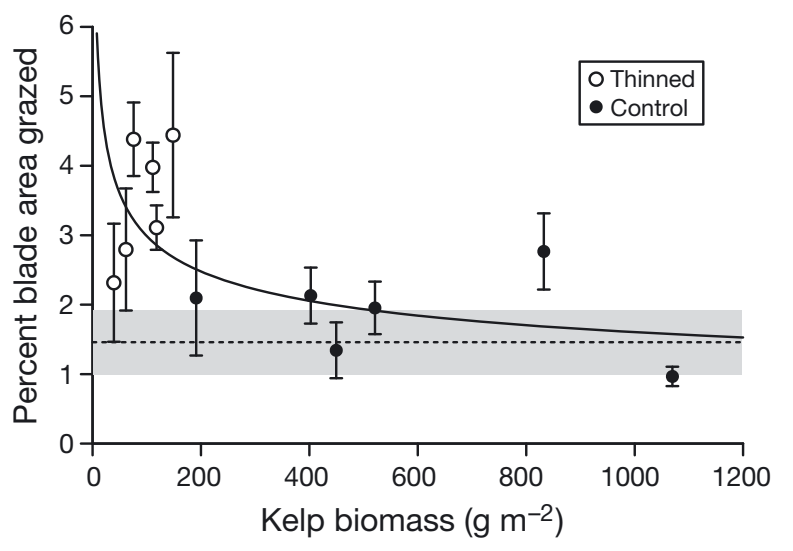

Fig. 6. Relationship between grazing intensity on kelp (SaCcharina latissima) by Lacuna vincta and kelp biomass in $1 \mathrm{~m}^{2}$ circular subplots from a manipulative field experiment at Duncan's Cove Protected in June/July 2013. Points are data from plots thinned of kelp by clearing (white circles) and control plots (black circles) at the end of the experiment. Data are mean $( \pm \mathrm{SE})$ percent of blade area grazed $(n=3-6)$. Also shown is the baseline grazing intensity at the start of the experiment in June (site average: dashed line, and 95\% CI: grey box). Regression line is the back-transformed prediction from fitting a linearized power model to data $\left(R^{2}=0.392, p<0.05\right)$

\section{Grazing dynamics across sites}

In accordance with observations within sites, grazing intensity of $L$. vincta on $S$. latissima also increased as standing kelp biomass decreased across sites (Fig. 7), and the power function was a significant fit to this non-linear relationship (Table 2). Grazing intensity on $L$. digitata across sites followed the same general trend (Fig. 7). However, there was greater variability and a relative scarcity of points around the regression line at lower kelp biomass (Fig. 7), and this relationship was non-significant (Table 2). If grazing intensity on $S$. latissima by $L$. vincta exceeds a threshold at $0.5-1 \%$, there is a stepwise increase in blade fragmentation with large wave events (Krumhansl \& Scheibling 2011b). The increase in grazing intensity with decreasing standing kelp biomass in our study exceeded even the more conservative 1\% threshold (Fig. 7). Grazing intensity was generally higher in the field experiment at Duncan's Cove Protected compared to 2008/2009 levels and exceeded the 1\% threshold in all but the highest biomass control plot (Figs. $6 \& 7$ ).

\section{DISCUSSION}

Both field observations and experimental manipulation supported our predictions of the response of
Lacuna vincta to changes in kelp abundance within a site. As we expected, snail density on kelp increased where kelp density and biomass were lower, suggesting a tendency for $L$. vincta to become concentrated on the remaining individuals as kelp becomes more sparse (Fig. 2C). We also observed higher grazing intensity on individual blades of Saccharina latissima following experimental thinning of kelp as predicted. In large part, this is likely a direct result of the increasing density of snails on those individuals rather than changes in the consumption rate of individual snails (although a functional response was not explicitly investigated). Furthermore, increases in snail density and grazing intensity with decreasing kelp abundance were consistently non-linear. Thus, changes in kelp abundance are expected to result in disproportionate changes in grazing pressure. Although the non-linear relationship was relatively weaker for grazing intensity as compared to snail density, this may have been an experimental artifact. Variability in the time for snails to recolonize following kelp thinning could explain why grazing intensity in some thinned plots was lower than expected (Fig. 6). Nonetheless, we found that individual thalli were increasingly grazed by L. vincta as kelp abundance decreased (Fig. 2C).

Variation in grazing intensity across sites was partly explained by kelp abundance. As we predicted, $S$. latissima was most heavily grazed at sites where standing kelp biomass was low. Evidence to support this prediction for Laminaria digitata was equivocal, suggesting that this species may be more resistant to herbivory by L. vincta. Material properties (strength, toughness) of the blade tissue would indicate that, of the 2 species, L. digitata is more resistant to breakage under stress and reductions in strength following grazing (Krumhansl et al. 2011) and perhaps more difficult to excavate. As with grazing within a site, grazing intensity on $S$. latissima increased non-linearly with decreasing kelp biomass across sites, although overall grazing was markedly lower. Methodological differences between the 2 periods (2008/ 2009 and 2013) may have contributed to the discrepancy in grazing intensity, as sectioning the blade before photographing (as in 2013) would capture more damage along the convoluted blade margins where grazing is concentrated (Johnson \& Mann 1986). Inter-annual variability in snail recruitment may also have been a contributing factor. Despite this difference, the total response of $L$. vincta to kelp abundance both within and across sites is (at least for $S$. latissima) most consistent with a type II shape (i.e. asymptotically declining). 


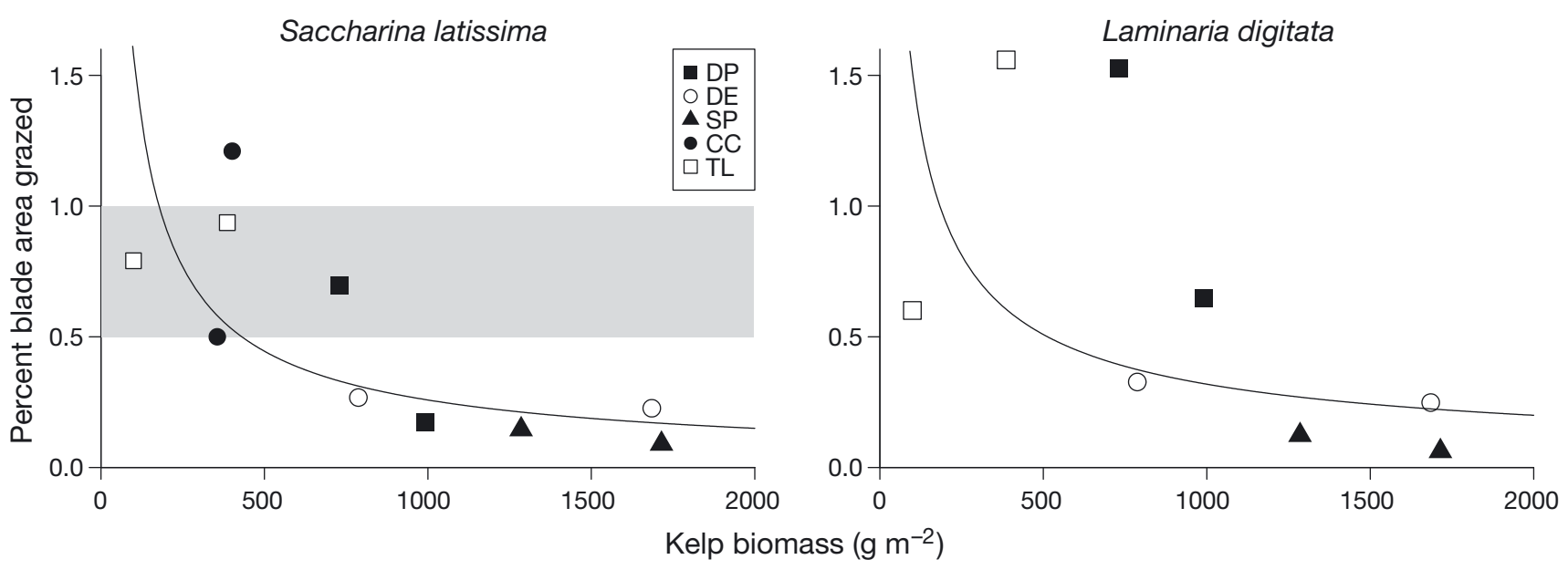

Fig. 7. Relationship between grazing intensity on kelp (Saccharina latissima and Laminaria digitata) by Lacuna vincta and standing kelp biomass at 5 sites (DP, DE, SP, CC, TL; see Table 1 for site abbreviations) in September 2008/2009. Data are mean percent of blade area grazed $(n=10-23$ thalli in each sampling period) against mean kelp biomass at each site $(n=8-9$ quadrats of $0.5 \mathrm{~m}^{2}$ ). Regression lines are back-transformed predictions from fitting linearized power models to data (S. latissima: $\mathrm{R}^{2}=0.601, \mathrm{p}<0.01 ;$ L. digitata: $\left.\mathrm{R}^{2}=0.309, \mathrm{p}=0.153\right)$. The grey box indicates a threshold range of grazing damage (0.5-1\% blade area grazed) beyond which a stepwise increase in blade fragmentation is expected with large wave events for S. latissima (Krumhansl \& Scheibling 2011b)

A concern with consumers showing a type II total response is their potential to cause Allee effects in their prey populations, i.e. inversely densitydependent population growth at low population size or density (Sinclair et al. 1998, Gascoigne \& Lipcius 2004, Courchamp et al. 2008). Under these circumstances, predation events are spread among more individuals at high population density (the dilution effect), but concentrated on fewer individuals when density or numbers are low (Courchamp et al. 2008). Likewise, we observed a 'dilution' of snails and grazing damage as kelp became increasingly dense. Consumer-driven Allee effects typically arise when the prey is secondary in the diet of the consumer, such that the consumer population is not depleted with its prey (Courchamp et al. 2008). Because $L$. vincta is a generalist herbivore, we do not expect a numerical response to changes in kelp abundance even though kelp is the preferred dietary item (Johnson \& Mann 1986). The fact that L. vincta is a mesograzer and typically does not consume kelp thalli entirely adds a further complication. Whether increasing grazing intensity with decreasing kelp abundance translates to a decline in the per capita rate of increase will depend to a large extent on the indirect effects of grazing on kelp.

Although direct consumption of macroalgae by mesograzers may be relatively minor, the indirect effects of grazing on growth, tissue loss, and mortality can be substantial (Johnson \& Mann 1986, Duggins et al. 2001, Krumhansl \& Scheibling 2011a,b,
Poore et al. 2014). The levels of grazing damage observed in this study represent a relatively small portion of the blade area, and the difference in grazing intensity between treatments in our field experiment did not cause an appreciable difference in thallus biomass. However, we expect increased grazing intensity at low kelp abundance to indirectly enhance the loss of biomass from individual thalli. Grazing damage by $L$. vincta increases the erosion rate of tissue from the distal end of kelp blades (Krumhansl \& Scheibling 2011a) and causes considerable blade fragmentation from $S$. latissima during large wave events if grazing intensity exceeds a threshold at 0.5-1\% (Krumhansl \& Scheibling 2011b). Our findings suggest that the removal of kelp by hurricane damage and recurrent outbreaks of Membranipora membranacea may intensify the direct impact (i.e. grazing damage) and in turn the indirect impact (i.e. increased erosion and fragmentation) of L. vincta on S. latissima. Furthermore, increases in grazing intensity beyond a relatively low threshold level, as we observed for $S$. latissima, presages even further losses of kelp biomass with subsequent storm events. Thus, disturbance-generated gaps in the canopy and low kelp biomass at sites following major thinning events are likely to persist due to high levels of blade erosion and fragmentation or possibly mortality if tissue loss occurs below the meristem. Defoliation of kelp canopy has been an important pre-requisite for replacement of kelp by other macroalgae (e.g. Codium fragile ssp. fragile) in this system in the past 
(Scheibling \& Gagnon 2006, 2009). This positive feedback between large-scale disturbances that impact the broader region and local-scale grazing could suppress kelp dominance and favour the persistence of competing turf-forming algae on subtidal reefs in Nova Scotia following canopy loss.

It has been proposed that shifts on temperate rocky reefs from canopy- to turf-dominated algal assemblages are facilitated by synergies between multiple drivers (Russell et al. 2009, Connell \& Russell 2010, Moy \& Christie 2012). That view is consistent with what we report here. Self-reinforcing feedbacks between multiple drivers are expected to produce synergies over time (Brook et al. 2008). Owing to a positive feedback between large-scale disturbances $(M$. membranacea outbreaks, hurricanes) and the mesograzer $L$. vincta, their combined effect on loss of kelp biomass from subtidal beds is likely greater than predicted from the sum of their independent effects. This synergy, which can drive the proliferation of turf-forming algae following initial removal of a foundation species such as kelp, underscores the importance of maintaining intact kelp populations (Eriksson et al. 2009, Falkenberg et al. 2012). However, the type II interaction that characterizes this particular grazer-kelp system renders it potentially unstable in the face of perturbation (Murdoch \& Oaten 1975, Sinclair et al. 1998). While intact kelp populations with high standing biomass should be more resilient to the indirect impacts of grazing, anticipated climate-mediated increases in the frequency and intensity of bryozoan infestations in Nova Scotia (Scheibling \& Gagnon 2009, Saunders et al. 2010) and hurricanes in the North Atlantic (Webster et al. 2005, Bender et al. 2010) should increasingly maintain kelp biomass within a range where $L$. vincta exerts a stronger top-down influence.

Ecosystem shifts in marine systems, such as shifts from kelp- to turf-dominated assemblages, appear to result from drivers that change the balance between production and consumption of key primary producers, which in turn alters their abundance (Burkepile \& Hay 2006, Connell et al. 2011, Harley et al. 2012). The replacement of $S$. latissima and other perennial macroalgae by filamentous turf-forming algae along the west and Skagerrak coasts of Norway and Sweden appears to be a consequence of ocean warming and eutrophication that favour both turfforming algae and epiphytic algae that decrease survival of kelp (Eriksson et al. 2002, Andersen et al. 2011, Moy \& Christie 2012). In South Australia, pervasive turfs that replace Ecklonia radiata kelp forests are facilitated by nutrient enrichment (Gorman et al.
2009), which may be exacerbated by synergism with future ocean warming and acidification (Russell et al. 2009, Connell \& Russell 2010). Although this system generally lacks strong herbivory (Connell et al. 2011), molluscan grazers have some capacity to mediate turf expansion (Russell \& Connell 2005, Falkenberg et al. 2014). Eutrophication also has caused the proliferation of ephemeral and filamentous algae in shallow subtidal habitats of the Baltic Sea, which is exacerbated by cascading effects of overfishing that decrease the abundance of invertebrate grazers (Eriksson et al. 2009). In contrast, subtidal fucoid algae in other areas of the Baltic and intertidal fucoids in Nova Scotia may be replaced by ephemeral algae following eutrophication even when grazers of the microscopic stages of ephemeral algae are present (Worm \& Lotze 2006). Our study highlights a special case where conditions that increase top-down control facilitate turf-forming algae because the dominant herbivore is a grazer of the canopy-forming species. These examples indicate that an understanding of the context-dependence of top-down and bottom-up forces, and the conditions that disrupt their relative strengths, is required to predict shifts from canopy- to turf-dominated assemblages on rocky reefs (Burkepile \& Hay 2006, Connell et al. 2011).

We have shown that large-scale disturbances that defoliate kelp beds can lead to increased densities of L. vincta on kelp and thus intensified grazing on surviving individuals, which could reinforce or accelerate the depletion of kelp and facilitate growth of turf-forming algae. Shifts to turf dominance likely impair important ecosystem functions attributed to kelp beds, including high primary production (Krumhansl \& Scheibling 2011a), habitat provision to important commercial species (Wharton \& Mann 1981) and the flow of energy and resource subsidies to less productive adjacent communities via kelp detritus (Filbee-Dexter \& Scheibling 2012, Kelly et al. 2012, Krumhansl \& Scheibling 2012). Owing to the nonindependent interaction between large-scale disturbances and local-scale grazing dynamics described here, projected climate-mediated declines in kelp biomass and detrital production (Krumhansl et al. 2014) may occur more rapidly than predicted. Our results underscore the importance of considering the potential for anthropogenic impacts to modify natural biological perturbations through ecologically mediated interactions when making an integrative assessment of how various drivers of ecosystem change combine across global, regional and local scales. 
Acknowledgements. We thank J. Lindley, F. Francis, C. Feehan, K. Sorochan, E. Simonson, D. Denley, K. Filbee-Dexter, A. Harding, J. LaRonde, O. Pisano and M. Harris for their assistance in the field and C. Robertson for help in the laboratory. We received helpful comments on the manuscript from D. Lyons and analyses from P. Petraitis, M. Barbeau and M. Wong. We thank K. Demes and 2 anonymous reviewers for their insightful comments leading to further improvements. This research was funded by a Discovery Grant to R.E.S. from the Natural Sciences and Engineering Research Council (NSERC) of Canada. J.M.O. was supported by a Dalhousie Killam Scholarship and an NSERC Canada Graduate Scholarship.

\section{LITERATURE CITED}

Airoldi L (1998) Roles of disturbance, sediment stress, and substratum retention on spatial dominance in algal turf. Ecology 79:2759-2770

Andersen GS, Steen H, Christie H, Fredriksen S, Moy FE (2011) Seasonal patterns of sporophyte growth, fertility, fouling, and mortality of Saccharina latissima in Skagerrak, Norway: implications for forest recovery. J Mar Biol 2011:690375, doi:10.1155/2011/690375

> Bender MA, Knutson TR, Tuleya RE, Sirutis JJ, Vecchi GA, Garner ST, Held IM (2010) Modeled impact of anthropogenic warming on the frequency of intense Atlantic hurricanes. Science 327:454-458

Benedetti-Cecchi L, Pannacciulli F, Bulleri F, Moschella PS, Airoldi L, Relini G, Cinelli F (2001) Predicting the consequences of anthropogenic disturbance: large-scale effects of loss of canopy algae on rocky shores. Mar Ecol Prog Ser 214:137-150

Brook BW, Sodhi NS, Bradshaw CJA (2008) Synergies among extinction drivers under global change. Trends Ecol Evol 23:453-460

Burkepile DE, Hay ME (2006) Herbivore vs. nutrient control of marine primary producers: context-dependent effects. Ecology 87:3128-3139

> Connell SD, Russell BD (2010) The direct effects of increasing $\mathrm{CO}_{2}$ and temperature on non-calcifying organisms: increasing the potential for phase shifts in kelp forests. Proc R Soc Lond B Biol Sci 277:1409-1415

Connell SD, Russell BD, Turner TJ, Shepherd SA and others (2008) Recovering a lost baseline: missing kelp forests from a metropolitan coast. Mar Ecol Prog Ser 360:63-72

> Connell SD, Russell BD, Irving AD (2011) Can strong consumer and producer effects be reconciled to better forecast 'catastrophic' phase-shifts in marine ecosystems? J Exp Mar Biol Ecol 400:296-301

Courchamp F, Berec L, Gascoigne J (2008) Allee effects in ecology and conservation. Oxford University Press, New York, NY

> Crain CM, Kroeker K, Halpern BS (2008) Interactive and cumulative effects of multiple human stressors in marine systems. Ecol Lett 11:1304-1315

> Duggins D, Eckman JE, Siddon CE, Klinger T (2001) Interactive roles of mesograzers and current flow in survival of kelps. Mar Ecol Prog Ser 223:143-155

> Eriksson BK, Johansson G, Snoeijs P (2002) Long-term changes in the macroalgal vegetation of the inner Gullmar Fjord, Swedish Skagerrak coast. J Phycol 38: 284-296

Eriksson BK, Ljunggren L, Sandström A, Johansson G and others (2009) Declines in predatory fish promote bloomforming macroalgae. Ecol Appl 19:1975-1988

- Fagan WF, Holmes EE (2006) Quantifying the extinction vortex. Ecol Lett 9:51-60

> Falkenberg LJ, Russell BD, Connell SD (2012) Stability of strong species interactions resist the synergistic effects of local and global pollution in kelp forests. PLoS ONE 7: e33841, doi:10.1371/journal.pone.0033841

Falkenberg LJ, Connell SD, Russell BD (2014) Herbivorymediates the expansion of an algal habitat under nutrient and $\mathrm{CO}_{2}$ enrichment. Mar Ecol Prog Ser 497: $87-92$

> Feehan C, Scheibling RE, Lauzon-Guay JS (2012) An outbreak of sea urchin disease associated with a recent hurricane: support for the 'killer storm hypothesis' on a local scale. J Exp Mar Biol Ecol 413:159-168

> Filbee-Dexter K, Scheibling RE (2012) Hurricane-mediated defoliation of kelp beds and pulsed delivery of kelp detritus to offshore sedimentary habitats. Mar Ecol Prog Ser 455:51-64

Fralick RA, Turgeon KW, Mathieson AC (1974) Destruction of kelp populations by Lacuna vincta (Montagu). Nautilus 88:112-114

Gascoigne JC, Lipcius RN (2004) Allee effects driven by predation. J Appl Ecol 41:801-810

Gilpin ME, Soulé ME (1986) Minimum viable populations: processes of extinction. In: Soulé ME (ed) Conservation biology: the science of scarcity and diversity. Sinauer Associates, Sunderland, MA, p 19-34

Gorman D, Russell BD, Connell SD (2009) Land-to-sea connectivity: linking human-derived terrestrial subsidies to subtidal habitat change on open rocky coasts. Ecol Appl 19:1114-1126

Halpern BS, McLeod KL, Rosenberg AA, Crowder LB (2008) Managing for cumulative impacts in ecosystem-based management through ocean zoning. Ocean Coast Manag 51:203-211

> Harley CDG, Randall Hughes A, Hultgren KM, Miner BG and others (2006) The impacts of climate change in coastal marine systems. Ecol Lett 9:228-241

Harley CDG, Anderson KM, Demes KW, Jorve JP, Kordas RL, Coyle TA, Graham MH (2012) Effects of climate change on global seaweed communities. J Phycol 48: 1064-1078

Hobbs RJ, Higgs E, Harris JA (2009) Novel ecosystems: implications for conservation and restoration. Trends Ecol Evol 24:599-605

> Hughes TP, Connell JH (1999) Multiple stressors on coral reefs: a long-term perspective. Limnol Oceanogr 44: 932-940

> Johnson CR, Mann KH (1986) The importance of plant defense abilities to the structure of subtidal seaweed communities: the kelp Laminaria longicruris de la Pylaie survives grazing by the snail Lacuna vincta (Montagu) at high population densities. J Exp Mar Biol Ecol 97: 231-267

> Kelly JR, Krumhansl KA, Scheibling RE (2012) Drift algal subsidies to sea urchins in low-productivity habitats. Mar Ecol Prog Ser 452:145-157

> Krumhansl KA, Scheibling RE (2011a) Detrital production in Nova Scotian kelp beds: patterns and processes. Mar Ecol Prog Ser 421:67-82

> Krumhansl KA, Scheibling RE (2011b) Spatial and temporal variation in grazing damage by the gastropod Lacuna vincta in Nova Scotian kelp beds. Aquat Biol 13:163-173 
Krumhansl KA, Scheibling RE (2012) Production and fate of kelp detritus. Mar Ecol Prog Ser 467:281-302

Krumhansl KA, Lee JM, Scheibling RE (2011) Grazing damage and encrustation by an invasive bryozoan reduce the ability of kelps to withstand breakage by waves. J Exp Mar Biol Ecol 407:12-18

Krumhansl KA, Lauzon-Guay JS, Scheibling RE (2014) Modeling effects of climate change and phase shifts on detrital production of a kelp bed. Ecology 95:763-774

Lyons DA, Benedetti-Cecchi L, Frid CLJ, Vinebrooke RD (in press) Modifiers of impacts on marine ecosystems: disturbance regimes, multiple stressors and receiving environments. In: Crowe TP, Austen MC, Frid CLJ (eds) Marine ecosystems: human impacts on biodiversity, ecosystem functioning and services. Cambridge University Press, Cambridge

Mann KH (1972) Ecological energetics of the seaweed zone in a marine bay on the Atlantic Coast of Canada. I. Zonation and biomass of seaweeds. Mar Biol 12:1-10

> Moy FE, Christie H (2012) Large-scale shift from sugar kelp (Saccharina latissima) to ephemeral algae along the south and west coast of Norway. Mar Biol Res 8:309-321

Murdoch WW, Oaten A (1975) Predation and population stability. Adv Ecol Res 9:1-131

Paine RT, Tegner MJ, Johnson EA (1998) Compounded perturbations yield ecological surprises. Ecosystems 1: 535-545

> Perkol-Finkel S, Airoldi L (2010) Loss and recovery potential of marine habitats: an experimental study of factors maintaining resilience in subtidal algal forests at the Adriatic Sea. PLoS ONE 5:e10791, doi:10.1371/journal. pone.0010791

Poore AGB, Gutow L, Pantoja JF, Tala F, Madariaga DJ, Thiel M (2014) Major consequences of minor damage: impacts of small grazers on fast-growing kelps. Oecologia 174:789-801

R Core Team (2012) R: a language and environment for statistical computing. R Foundation for Statistical Computing, Vienna. Available at www.R-project.org/

Russell BD, Connell SD (2005) A novel interaction between nutrients and grazers alters relative dominance of marine habitats. Mar Ecol Prog Ser 289:5-11

Russell BD, Thompson JI, Falkenberg LJ, Connell SD (2009) Synergistic effects of climate change and local stressors: $\mathrm{CO}_{2}$ and nutrient-driven change in subtidal rocky habitats. Glob Change Biol 15:2153-2162

Sala OE, Chapin FS III, Armesto JJ, Berlow E and others (2000) Global biodiversity scenarios for the year 2100. Science 287:1770-1774

Saunders M, Metaxas A (2008) High recruitment of the introduced bryozoan Membranipora membranacea is associated with kelp bed defoliation in Nova Scotia, Canada. Mar Ecol Prog Ser 369:139-151

Saunders M, Metaxas A, Filgueira R (2010) Implications of warming temperatures for population outbreaks of a nonindigenous species (Membranipora membranacea, Bryozoa) in rocky subtidal ecosystems. Limnol Oceanogr 55:1627-1642

Editorial responsibility: Lisandro Benedetti-Cecchi, Pisa, Italy
Scheibling RE, Gagnon P (2006) Competitive interactions between the invasive green alga Codium fragile ssp. tomentosoides and native canopy-forming seaweeds in Nova Scotia (Canada). Mar Ecol Prog Ser 325:1-14

Scheibling RE, Gagnon P (2009) Temperature-mediated outbreak dynamics of the invasive bryozoan Membranipora membranacea in Nova Scotian kelp beds. Mar Ecol Prog Ser 390:1-13

> Scheibling RE, Hennigar AW, Balch T (1999) Destructive grazing, epiphytism, and disease: the dynamics of sea urchin - kelp interactions in Nova Scotia. Can J Fish Aquat Sci 56:2300-2314

Scheibling RE, Feehan C, Lauzon-Guay JS (2010) Disease outbreaks associated with recent hurricanes cause mass mortality of sea urchins in Nova Scotia. Mar Ecol Prog Ser 408:109-116

Sinclair ARE, Pech RP, Dickman CR, Hik D, Mahon P, Newsome AE (1998) Predicting effects of predation on conservation of endangered prey. Conserv Biol 12:564-575

Strain EM, Thomson RJ, Micheli F, Mancuso FP, Airoldi L (2014) Identifying the interacting roles of stressors in driving the global loss of canopy-forming to mat-forming algae in marine ecosystems. Glob Change Biol 20: 3300-3312

Trexler JC, McCulloch CE, Travis J (1988) How can the functional response best be determined? Oecologia 76: 206-214

van Katwijk MM, Schmitz GHW, Gasseling AP, van Avesaath PH (1999) Effects of salinity and nutrient load and their interaction on Zostera marina. Mar Ecol Prog Ser 190:155-165

- Watanabe S, Scheibling RE, Metaxas A (2010) Contrasting patterns of spread in interacting invasive species: Membranipora membranacea and Codium fragile off Nova Scotia. Biol Invasions 12:2329-2342

> Webster PJ, Holland GJ, Curry JA, Chang HR (2005) Changes in tropical cyclone number, duration, and intensity in a warming environment. Science 309:1844-1846

Wernberg T, Thomsen MS, Tuya F, Kendrick GA, Staehr PA, Toohey BD (2010) Decreasing resilience of kelp beds along a latitudinal temperature gradient: potential implications for a warmer future. Ecol Lett 13:685-694

- Wernberg T, Russell BD, Moore PJ, Ling SD and others (2011) Impacts of climate change in a global hotspot for temperate marine biodiversity and ocean warming. J Exp Mar Biol Ecol 400:7-16

Wernberg T, Smale DA, Tuya F, Thomsen MS and others (2012) An extreme climatic event alters marine ecosystem structure in a global biodiversity hotspot. Nat Clim Change 3:78-82

Wharton WG, Mann KH (1981) Relationship between destructive grazing by the sea urchin, Strongylocentrotus droebachiensis, and the abundance of American lobster, Homarus americanus, on the Atlantic coast of Nova Scotia. Can J Fish Aquat Sci 38:1339-1349

> Worm B, Lotze HK (2006) Effects of eutrophication, grazing, and algal blooms on rocky shores. Limnol Oceanogr 51: 569-579

Submitted: September 22, 2014; Accepted: January 5, 2015 Proofs received from author(s): February 6, 2015 